\title{
Distribution of Taraxacum microspecies along soil property gradients in salt and brackish meadows on the Polish Baltic coast
}

\author{
Beata Bosiacka ${ }^{1 \star}$, Helena Więcław ${ }^{1}$, Paweł Marciniuk², Marek Podlasiński ${ }^{3}$ \\ ${ }^{1}$ Department of Plant Taxonomy and Phytogeography, Faculty of Biology, University of Szczecin, Wąska 13, 71-415 \\ Szczecin, Poland \\ ${ }^{2}$ Department of Botany, University of Podlasie, Prusa 12, 08-110 Siedlce, Poland \\ ${ }^{3}$ Department of Land Recultivation and Environmental Chemistry, West Pomeranian University of Technology, \\ Słowackiego 14, 71-434 Szczecin, Poland
}

\begin{abstract}
The vegetation of protected salt meadows along the Baltic coast is fairly well known; however, dandelions have been so far treated as a collective species. The aim of our study was to examine the microspecies diversity of the genus Taraxacum in Polish salt and brackish coastal meadows and to analyse soil property preferences of the dandelion microspecies identified. In addition, we analysed the relations between soil properties and vegetation patterns in dandelion-supporting coastal meadows (by canonical correspondence analysis). The salt and brackish meadows along the Polish Baltic coast we visited were found to support a total of 27 dandelion microspecies representing 5 sections. Analysis of vegetation patterns showed all the soil parameters (C:N ratio, organic matter content, $\mathrm{pH}$, concentration of $\mathrm{Mg}, \mathrm{P}, \mathrm{K}$, electrolytic conductivity of the saturated soil extract $\mathrm{EC}_{\mathrm{e}}$ ) to explain $32.07 \%$ of the total variance in the species data. The maximum abundance of most dandelion microspecies was associated with the highest soil fertility, moderate $\mathrm{pH}$ values and organic matter content, and with the lowest magnesium content and soil salinity. The exceptions were T. latissimum, T. stenoglossum, T. pulchrifolium and T. lucidum the occurrence of which was related to the lowest soil fertility and the highest salinity. In addition, several microspecies ( $T$. leptodon, T. gentile, T. haematicum, T. fusciflorum and T. balticum) were observed at moderate C:N ratios and $\mathrm{EC}_{\mathrm{e}}$. Four other microspecies ( $T$. infestum, T. cordatum, T. hamatum, T. sertatum) occurred at the lowest $\mathrm{pH}$ and organic matter content. The information obtained increases the still insufficient body of knowledge on ecological spectra of individual dandelion microspecies, hence their potential indicator properties.
\end{abstract}

Keywords: coastal grasslands; dandelion microspecies; plant species composition, soil properties

\section{Introduction}

The genus Taraxacum (Asteraceae, Cichorioideae) comprises about 2800 microspecies with various reproductive systems, which can be grouped - based on their morphology and ecology - into about 60 sections (Kirschner and Štěpánek 1996, Kirschner et al. 2015). Most dandelion microspecies belong to the polyploid-agamospermous hybrid complexes. In addition, the genus includes some primarily diploid and sexual taxa. Parthenogenic seed production, definitely a dominant seed production mode in the genus, has resulted in maintenance of genetic differences, even small ones, among the microspecies (Kirschner and Štěpánek 1996). These genetic differences underpin the morphological, biochemical and ecological variability of dandelions (van Dijk 2003). Due to reproductive isolation, many agamospermous microspecies can coexist in the same area (Uhlemann 2001). Despite the growing interest in the supraspecific taxonomy of Taraxacum, knowledge about the dandelion flora is still far from complete. Reports documenting the presence of single dandelion microspecies are relatively frequent (e.g. Lundevall and Øllgaard 2006, Uhlemann et al. 2007, Trávniček

* Corresponding author, e-mail: bebos@univ.szczecin.pl 
et al. 2008, Marciniuk et al. 2012). On the other hand, comprehensive studies of the dandelion flora from larger areas in Europe are rather rare. The identification guide to dandelions of Great Brittan and Ireland (Dudman and Richards 1997) includes keys to different recognized taxa representing nine sections and provides information on the biology, preferred habitats, distribution and status of the genus in the British Isles. Trávníček et al. (2010) described the dandelion flora known to date from the Czech Republic; their description contains identification keys and considers the morphology, ecology, coenology and distribution of 179 dandelion taxa. Some monographic studies focus on Taraxacum section Palustria, one of the most threatened dandelion groups. Kirschner and Štěpanek (1998) described the morphology, most common habitats and geographical distribution of 127 dandelion taxa of the section Palustria in Europe. Schmid (2002) reported on the morphology, ecology, coenology, distribution and risk status of 24 dandelion taxa of the section Palustria in southern Germany. The same dandelion group was examined in Poland and described by Marciniuk (2012) whose monograph is complete with a key, a description of the morphological characteristics, habitat requirements and distribution of 23 taxa of the section Palustria. Dandelions are plants typical of open grassland ecosystems. At the section level, they are assigned to habitats of varying moisture and fertility (e.g. Kirschner and Štěpanek 1998, Trávníček and Vašut 2011). As demonstrated by some more detailed observations, individual microspecies within a section may be indicative of the grassland management type and shortterm environmental improvement or deteriorations (Oosterveld 1978, 1983).

Grassland ecosystems are under threat because traditional management practices, such as mowing and grazing, have been largely abandoned, giving rise to progressive succession (Muller 2002, Isselstein et al. 2005). Particularly threatened are coastal salt grasslands, as they shrink or completely disappear, especially when natural factors (e.g. low seawater salinity) act in concert with anthropogenic effects. This is the case along the coast of the Baltic Sea, a microtidal (to almost atidal) sea of a naturally low salinity (Emeis et al. 2003). In Poland, the geomorphological structure of a coastline dominated by sandy dunes and cliff sections is additionally unfavourable to seawater incursions. Marsh areas favouring the development of halophytic vegetation, are found on the coast in only a few locations, such as the shores of estuaries and shallow embayments (Herbich 2004, Bosiacka 2012). Salt grasslands along the Baltic coast have developed mainly from brackish reed beds as a result of their centuries-long traditional, extensive use for grazing and mowing (Dijkema 1990). Hulisz et al. (2016) found that the seacoast vegetation patterns along the Baltic Sea shore were inconsistent with the salinity gradient of the open sea water, but were significantly dependent on specific, local conditions, e.g. factors that determined long-term seawater stagnation and intensive evaporation (resulting in soil salinity increase) and grassland management. Intensive livestock grazing produces a low turf, homogeneous and species-poor. On the other hand, cessa- tion of hay-making or grazing leads to the development of homogeneous, tall vegetation and to the withdrawal of heliophytic species (Bakker 2012).The Polish coastal salt grasslands are assigned to the EU habitat type 1330 Atlantic salt meadows (Interpretation Manual, 2003). This habitat is protected under the Natura 2000 network (Habitats Directive 92/43/EEC). Although the vegetation of salt meadows along the Baltic coast is fairly well known (Dijkema 1990, Wanner 2009, Bosiacka 2012, Hulisz et al. 2016), dandelions have been so far treated as a collective species Taraxacum officinale agg. Our research is meant to contribute to the filling of this gap and, moreover, to find out whether different Taraxacum microspecies prefer different microhabitats.

The aim of our study was to examine the microspecies diversity of the genus Taraxacum in Polish salt and brackish coastal meadows and to analyse soil property preferences of the dandelion microspecies identified. In addition, we analysed the relations between soil properties and the vegetation patterns in dandelion-supporting coastal meadows.

\section{Materials and methods}

\section{Study area}

Our study encompassed all the salt and brackish meadows along the Polish coast, of which there are currently few. Due to natural and anthropogenic factors limiting the extent of this habitat type along the Polish Baltic Sea coast, salt and brackish meadows occupy a small area compared to that along the south-western coast of the Baltic Sea or the North Sea coast. At present, short grasslands with halophytes cover as little as a few hundred hectares in northern Poland (Bosiacka 2012). Marsh areas conducive to seawater incursions are found in the north-western part of Poland on the shores of Szczecin Lagoon, as well as on dozens of islands in the River Świna storm delta, and in the eastern part of the Polish coast, i.e. in Puck Bay. Nevertheless, a large part of the habitat potentially amenable to salt meadow presence in those areas is overgrown by beds of reed (Phragmitetum australis). In addition, brackish meadows supporting some halophytes have developed around several coastal lakes in the central part of the Polish Baltic coast. In NW Poland, sites located close to the seashore (3-8 km away from it) show the presence of several salt marshes resulting from the ascending brine (Bosiacka et al. 2011). The origin of brine in north-western Poland is associated with the culmination of the Mid-Polish Trough (Krzywiec 2009). The Cenozoic groundwater salinity is mainly a result of the ascending Mesozoic relic seawater. In addition, the groundwater salinity in the anticline areas located in a close proximity to the seacoast may be in part a remnant of the juvenile relic water left by the Littorina Sea (Kaczor 2006).

Not all the sites of the salt and brackish meadows along the Polish Baltic coast were observed to support dandelions. In fact, they were recorded at as few as eight sites only (Fig. 1). 


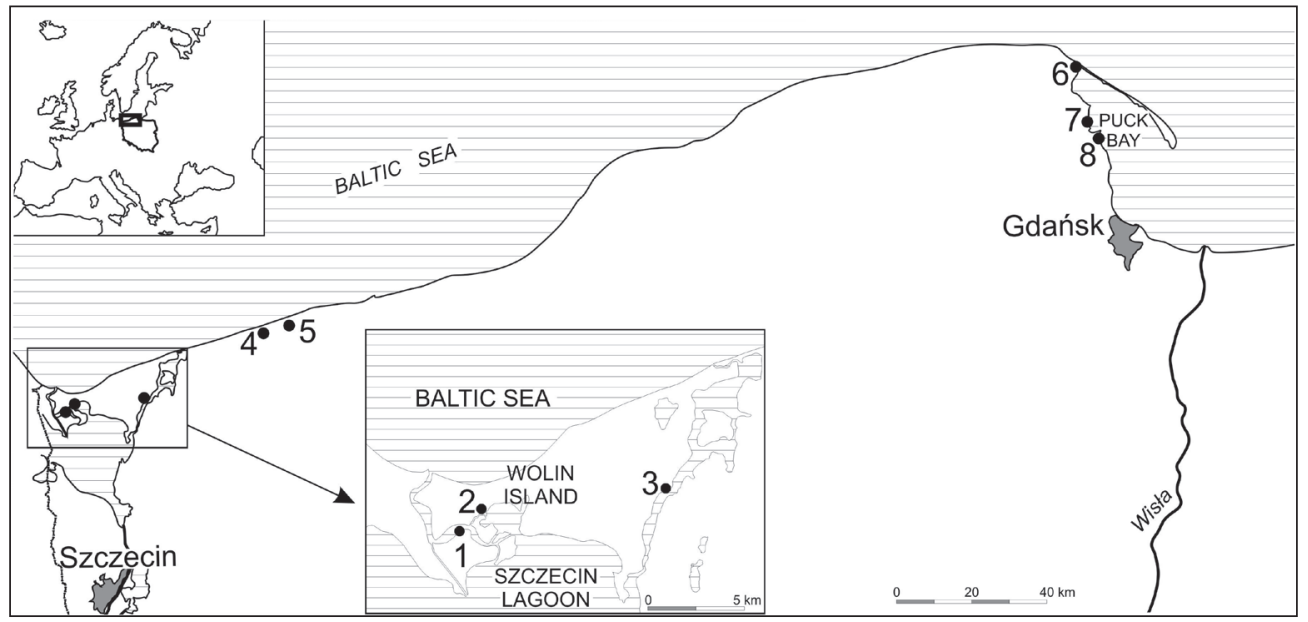

Fig. 1. Study area; 1-8 sites in Polish salt and brackish coastal meadows supporting the dandelion growth.

\section{Field sampling}

Field data were collected in April and May of 2013 and 2014. In all, 32 plots were sampled (all located in patches supporting dandelions). The plots (relevés) were $2 \mathrm{~m} \mathrm{x} 2 \mathrm{~m}$ in size. The species cover in each plot was estimated using a nine-grade scale (van der Maarel 1979). Both vascular plants and bryophytes were recorded. The vascular plant nomenclature follows Mirek et al. (2002), the system of Ochyra et al. (2003) being followed for the bryophyte nomenclature. Dandelion specimens were collected from each plot as vouchers and were deposited in the University of Szczecin herbarium (SZUB). For each relevé, three soil samples from the plant root zone $(0-25 \mathrm{~cm})$ were collected with Egner's soil sampler. The three samples were blended to form a single sample, representative of a given relevé, to be used in chemical analyses.

\section{Laboratory analyses}

Soil samples were dried at room temperature and sieved to remove fractions larger than $1 \mathrm{~mm}$. The following properties were determined in the sieved material: (1) the organic matter content, as loss on ignition at $550^{\circ} \mathrm{C}$, (2) soil pH, potentiometrically in $1 \mathrm{M} \mathrm{KCl}$, (3) electrolytic conductivity of the saturated soil extract $\left(\mathrm{EC}_{\mathrm{e}}\right)$, conductometrically, (4) the content of available forms of potassium $\left(\mathrm{K}_{2} \mathrm{O}\right)$ in $0.5 \mathrm{M} \mathrm{HCl}$, by atomic absorption spectroscopy, AAS (American Society of Agronomy method), (5) the content of available forms of magnesium (MgO) in $0.5 \mathrm{M} \mathrm{HCl}$, by AAS, (6) the content of available forms of phosphorus $\left(\mathrm{P}_{2} \mathrm{O}_{5}\right)$ in $0.5 \mathrm{M} \mathrm{HCl}$, colorometrically, (7) the total carbon and nitrogen contents in air-dried triturated soil samples, using a CHNS analyser (Costech Analytical Technologies Inc.).

The soil salinity was determined based on the conductivity of the saturated soil extract $\left(\mathrm{EC}_{\mathrm{e}}\right)$. The following scale was used to classify salinity ranges obtained: non-saline soils (0-2 dS m $\left.{ }^{-1}\right)$; slightly saline soils (2-4 $\left.\mathrm{dS} \mathrm{m}^{-1}\right)$; moderately saline soils (4-8 $\left.\mathrm{dS} \mathrm{m}^{-1}\right)$; strongly saline soils $\left(8-16 \mathrm{dS} \mathrm{m}^{-1}\right)$; very strongly saline soils (>16 dS m${ }^{-1}$ ) (Richards 1954).

\section{Data analysis}

Relationships between plant species composition and soil properties were determined using the CANOCO v. 4.5 software package (ter Braak and Šmilauer 2002). Plant species distribution patterns in relation to soil properties were determined by the canonical correspondence analysis (CCA), after detrended correspondence analysis (DCA) had detected a unimodal structure of the species data (the gradient length represented by the first ordination axis exceeded $3 \mathrm{SD}$ ). The data were not transformed. Tests of significance of the first and all canonical axes were performed for the statistical assessment of the relation between plant species composition and environmental variables (Monte Carlo test: 499 permutations under the reduced model).

The Monte Carlo permutation test was further applied to determine the statistical significance of environmental variables in explaining the plant species composition. For this purpose, the stepwise "forward selection" of explanatory variables (available in CANOCO) was used. The procedure started with selection of the best explanatory variable (a variable that best explains the total data variance), and the sequence of other variables was determined according to their decreasing importance in explaining the total variance in the data set, together with the previously selected variables. To this end, an "extra fit" (Lambda A) value was calculated, the value representing a change in the sum of all the CCA eigenvalues when another variable is added. Additionally, the statistical significance of each variable was determined. Variation in the plant species composition explained by environmental variables included in the analysis was expressed as a percentage representing the ratio of the sum of all canonical eigenvalues to the value of total variance (total inertia). Variation in the species composition explained by individual variables was calculated from the ratio of Lambda A to the total variance (total inertia), expressed as a percentage.

The basic statistics (interquartile ranges of values, medians, outlier values, extreme values) were calculated for each soil property associated with individual dandelion microspe- 
cies. Ranges of those properties were illustrated by individual box and whisker plots. Relationships between the presence of individual dandelion microspecies (for 6 microspecies occurring in more than 2 plots only) and soil parameters as well as between the number of dandelion microspecies per plot and soil parameters were examined using Spearman's rank correlation test (STATISTICA StatSoft v. 10.0).

Plant communities were distinguished in the set of phytosociological relevés by the hierarchical divisive cluster analysis performed with TWINSPAN v. 2.3 software (Hill and Šmilauer 2005).

\section{Results}

The salt and brackish meadows along the Polish Baltic coast visited were found to support a total of 27 microspecies representing 5 sections: 1 microspecies of the section Palustria (T. balticum, an agamospermous tetraploid which does not produce pollen), 2 microspecies of the section Celtica (T. nordstedtii, an agamospermous hexaploid which does not produce pollen and T. gelertii, a pollen-producing agamospermous triploid), 6 microspecies of the section Hamata (T. fusciflorum, T. infestum, T. hamatum, T. hamatiforme, T. kernianum, T. lancidens, all pollen-producing agamospermous triploids), 1 microspecies of the section Borea (T. ostenfeldii, an agamospermous triploid which does not produce pollen) and 17 microspecies of the section Taraxacum (Ruderalia), all pollen-producing agamospermous triploids. The number of dandelion taxa at a site varied from 2 to 10 (in individual relevés: from 1 to 6 microspecies per $4 \mathrm{~m}^{2}$ ). The number of microspecies per plot was positively correlated with soil fertility, expressed as the $\mathrm{C}: \mathrm{N}$ ratio (inversely proportional to soil fertility) and negatively correlated with soil salinity, $\mathrm{K}$ and $\mathrm{Mg}$ concentrations (Tab. 1). No dandelions were found in the most waterlogged salt meadows (where stagnant water is observed even in April and May) or in salt meadows abandoned for a long time (which often experience encroachment of the robust common reed Phragmites australis). Most of the identified dandelion microspecies occurred in 1-2 plots. Only six microspecies were more frequent in coastal meadows and occurred in larger numbers: T. nordstedtii (in 12 plots, in the western part of the coast only), T. haematicum (in 10 plots), T. balticum (in 8 plots, in the western part of the coast only), T. hamatiforme (in 7 plots), T. gelertii (in 5 plots) and T. sellandii (in 4 plots).

Analysis of vegetation patterns in the dandelion-supporting coastal meadows (CCA) showed all the environmental variables (soil parameters) to explain $32.07 \%$ of the total variance in the species data. The first axis and all the canonical axes were significant as tested by the unconstrained Monte Carlo permutation test $(\mathrm{p}=0.002)$. Results of the stepwise forward selection of variables revealed five out of the seven variables considered ( $\mathrm{C}: \mathrm{N}$, organic matter, $\mathrm{pH}, \mathrm{Mg}, \mathrm{EC}_{\mathrm{e}}$ ) ) to be statistically significant and explain $26.45 \%$ of the total variance in the plant species composition. The largest amount of the total variance $(7.31 \%)$ was explained by soil fertility (Tab. 2). The maximum abundance of most dandelion microspecies was associated with the highest soil fertility (soil fertility is inversely proportional to the C:N ratio), moderate $\mathrm{pH}$ values and organic matter content, and with the lowest magnesium content and salinity (Fig. 2). The exceptions were Taraxacum latissimum, T. stenoglossum, T. pulchrifolium and T. lucidum the occurrence of which was related to the lowest soil fertility (i.e. the highest C:N ratios) and the highest salinity. In addition, several microspecies (T. leptodon, T. gentile, T. haematicum, T. fusciflorum and T. balticum) were observed at moderate $\mathrm{C}: \mathrm{N}$ ratios and $\mathrm{EC}_{\mathrm{e}}$. Four other microspecies ( $T$. infestum, T. cordatum, T. hamatum, T. sertatum) occurred at the lowest $\mathrm{pH}$ and organic matter content. Fig. 3 shows in detail the ranges of soil properties in relation to the different dandelion microspecies. With re-

Tab. 2. Forward selection of explanatory variables with the significance test for variables (soil parameters) explaining variance in the Taraxacum species composition; ${ }^{\star}$ denotes $\mathrm{p}<0.05$, org. mat. - organic matter content, $\mathrm{EC}_{\mathrm{e}}$ - electrolytic conductivity.

\begin{tabular}{lcccc}
\hline Variables & $\begin{array}{c}\text { LambdaA } \\
\text { (variance) }\end{array}$ & $\begin{array}{c}\text { Explained data } \\
\text { variance [\%] }\end{array}$ & F-ratio & p-value \\
\hline C:N & $0.29^{*}$ & 7.31 & 2.37 & 0.002 \\
org. mat. & $0.21^{*}$ & 5.29 & 1.77 & 0.002 \\
$\mathrm{pH}$ & $0.20^{*}$ & 5.04 & 1.77 & 0.010 \\
$\mathrm{Mg}$ & $0.18^{\star}$ & 4.53 & 1.60 & 0.006 \\
$\mathrm{ECe}$ & $0.17^{\star}$ & 4.28 & 1.48 & 0.028 \\
$\mathrm{P}$ & 0.11 & 2.77 & 1.20 & 0.452 \\
$\mathrm{~K}$ & 0.11 & 2.77 & 1.14 & 0.546 \\
\hline
\end{tabular}

Tab. 1. Results of Spearman's rank correlation test between the number and occurrence of Taraxacum microspecies and soil parameters, * denotes $\mathrm{p}<0.05, \mathrm{EC}_{\mathrm{e}}-$ electrolytic conductivity.

\begin{tabular}{|c|c|c|c|c|c|c|c|}
\hline Taxon & $\begin{array}{c}\text { organic matter } \\
\text { content [\%] }\end{array}$ & $\mathrm{C}: \mathrm{N}$ & $\mathrm{EC}_{\mathrm{e}}\left[\mathrm{dS} \mathrm{m}^{-1}\right]$ & $\mathrm{pH}$ & $\begin{array}{c}\mathrm{P} \\
{\left[\mathrm{mg} \mathrm{kg}^{-1}\right]}\end{array}$ & $\mathrm{K}\left[\mathrm{mg} \mathrm{kg}^{-1}\right]$ & $\mathrm{Mg}\left[\mathrm{mg} \mathrm{kg}^{-1}\right]$ \\
\hline T. balticum & $0.452^{\star}$ & 0.175 & $0.373^{\star}$ & 0.159 & 0.192 & 0.164 & 0.334 \\
\hline T. gelertii & -0.241 & -0.255 & $-0.367^{\star}$ & 0.052 & -0.049 & -0.278 & -0.111 \\
\hline T. haematicum & $-0.369^{\star}$ & -0.098 & -0.006 & 0.259 & 0.158 & 0.016 & -0.131 \\
\hline T. hamatiforme & -0.048 & $-0.492^{\star}$ & $-0.417^{\star}$ & -0.159 & 0.168 & $-0.349^{*}$ & $-0.467^{\star}$ \\
\hline T. nordstedtii & -0.147 & $-0474^{*}$ & $-0.413^{\star}$ & -0.125 & 0.128 & -0.209 & -0.267 \\
\hline T. sellandii & 0.076 & -0.169 & -0.159 & -0.142 & 0.054 & -0.082 & 0.005 \\
\hline No. dandelion microspecies & -0.169 & $-0.552^{\star}$ & $-0.582^{\star}$ & -0.126 & 0.034 & $-0.389^{*}$ & $-0.361^{\star}$ \\
\hline
\end{tabular}



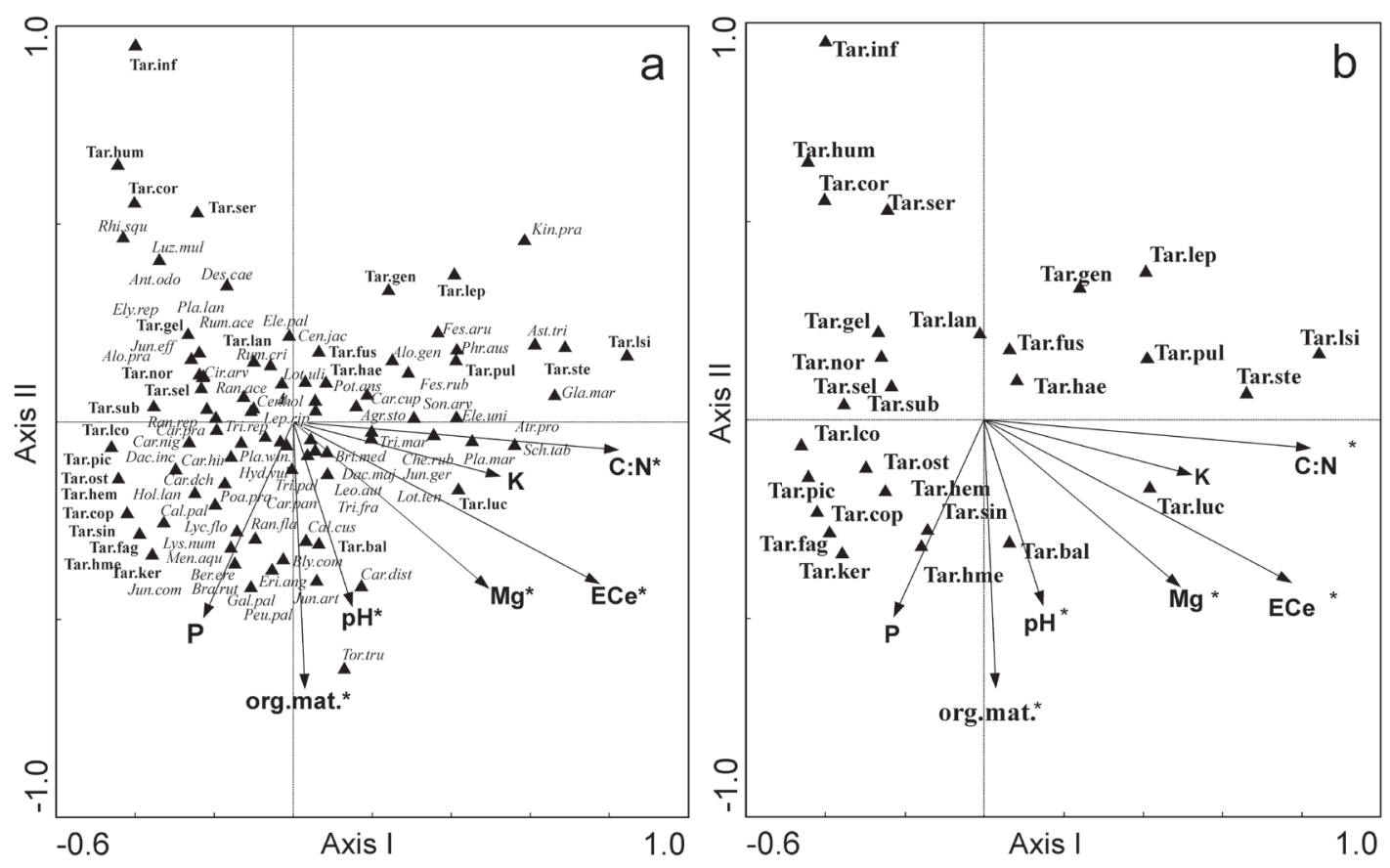

Fig. 2. Diagrams of species of Polish coastal meadows and soil properties ordination along the first two CCA axes: a) Taraxacum microspecies with the most common accompanying plant species, b) Taraxacum microspecies visible only; eigenvalues of Axis I and Axis II: 0.361 and 0.229 respectively; sum of all eigenvalues (total inertia): 3.971 ; sum of all canonical eigenvalues: $1.271 ;{ }^{\star}$ denotes statistically significant variables. Abbreviations of species names consist of the first three letters of a generic name and the first three letters of a species name (see Tab. 3), with exceptions: Tar.hme - Taraxacum hamatiforme, Tar.hum - Taraxacum hamatum, Tar.lco - Taraxacum laticordatum, Tar lsi - Taraxacum latissimum, Car.dist - Carex distans, Car.dch - Carex disticha; ECe - electrolytic conductivity.

gard to the soil salinity classes identified, slightly saline soils $\left(2-4 \mathrm{dS} \mathrm{m}^{-1}\right)$ supported the following microspecies: T. balticum, T. fusciflorum, T. gelertii, T. gentile, T. haematicum, T. hamatiforme, T. lucidum, T. nordstedtii, T. sellandii, T. stenoglossum, while moderately saline soils $\left(4-8 \mathrm{dS} \mathrm{m}^{-1}\right)$ were found to support T. balticum, T. haematicum, T. latissimum, T. leptodon and T. pulchrifolium. Other dandelion microspecies were recorded mainly in non-saline soils, in phytocoenoses developing on the edges of salt meadow patches. Results of Spearman's rank correlation tests applied to the six dandelion microspecies occurring in more than 2 plots (Tab. 1) showed significant direct association between T. balticum and the organic matter content and soil salinity, as well as a significant positive correlation between T. nordstedtii and $T$. hamatiforme and soil fertility expressed as the C:N ratio (inversely proportional to soil fertility). Negative correlations were observed between T. haematicum and the organic matter content; T. hamatiforme and soil salinity and $\mathrm{K}$ and $\mathrm{Mg}$ concentrations; T. nordstedtii and soil salinity.

The hierarchical divisive cluster analysis identified, in the first division, two groups of plant communities (Tab. 3). Cluster I showed the following species as indicators: Carex nigra, Cardamine pratensis and Taraxacum nordstedtii, cluster II being typified by Eleocharis uniglumis, Plantago maritima and Phragmites australis. This division largely coincides with the diversity of communities found in the western (sites 1-5) and eastern (sites 6-8) parts of the Polish coast. The following species are indicative of the further division of cluster I (dominant phytocoenoses in the western part of the coast): Juncus effusus, Holcus lanatus, Taraxacum hamatiforme (cluster III) and Triglochin maritimum, Calliergonella cuspidata, Taraxacum balticum (cluster IV). Taraxacum nordstedtii was recorded only in the western part of the coast, both in the meadow phytocoenoses from cluster III, growing on slightly saline or non-saline edges of salt marshes, and in the phytocoenoses from cluster IV, developing on low- or moderate salinity soils. Cluster III phytocoenoses seldom supported halophytes, while the frequent Taraxacum hamatiforme dominated among other dandelion microspecies. The following microspecies occurred exclusively in this group, but only in single plots: T. hamatum, T. infestum, $T$. kernianum, T. laticordatum, T. ostenfeldii, T. piceatum and T. sertatum. Phytocoenoses from cluster IV were characterized by a higher contribution of halophytes. Apart from T. nordstedtii, also frequent was T. balticum (in the western part of the coast only). The following species occurred exclusively in this group, but only in single plots: T. copidophyllum, T. fagerstroemii, T. hemicyclum, T. sinuatum and T. sublaeticolor. The following species are indicative of the further division of cluster II (phytocoenoses dominant in the eastern part of the coast, except for relevés/plots 4, 17, 20,21): Glaux maritima, Plantago maritima (cluster V) and Phragmites australis, Rumex crispus (cluster VI). Phytocoenoses from cluster $\mathrm{V}$ were characterized by the abundance of halophytes and a low contribution of Phragmites australis. T. stenoglossum and T. cordatum occurred exclusively in this group, but 

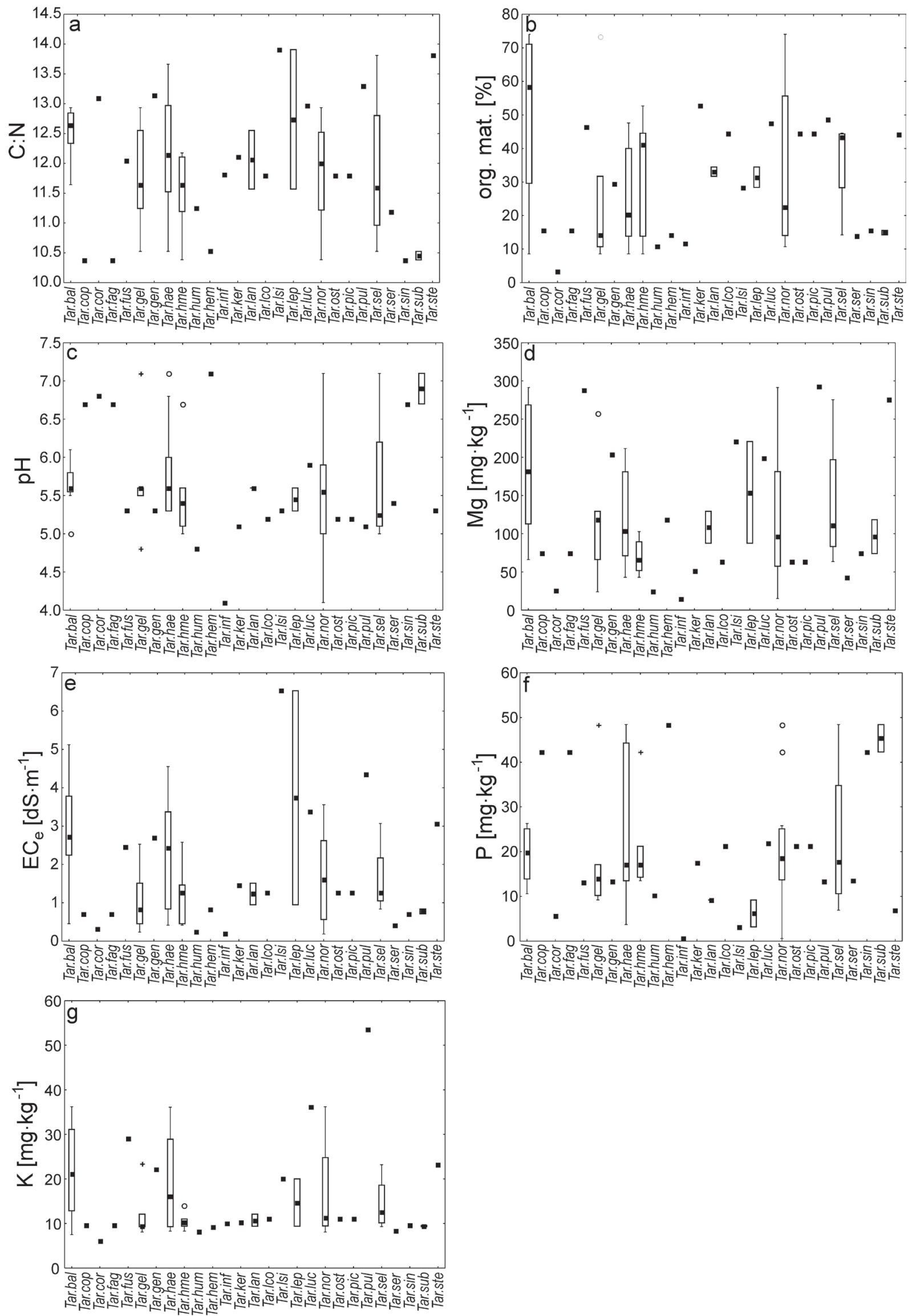

Fig. 3. The ranges of soil property values related to individual Taraxacum microspecies of Polish coastal meadows: a) C:N ratio, b) organic matter content, c) pH, d) $\mathrm{Mg}$ concentration, e) electrolytic conductivity $\left(\mathrm{EC}_{\mathrm{e}}\right)$ of the saturated soil extract, f) P concentration, g) K concentration. Grey boxes indicate $25-75 \%$ of the interquartile ranges of values, black boxes - the medians (with the exception of microspecies found in only one sample), white circles - outlier values, asterisk - extreme values. 
Tab. 3. Plant communities in Polish salt and brackish coastal meadows separated by the hierarchical divisive cluster analysis. Species indicative of the division into clusters are underlined.

\begin{tabular}{|c|c|c|c|c|c|c|c|c|c|c|c|c|c|c|c|c|c|c|c|c|c|c|c|c|c|c|c|c|c|c|c|c|}
\hline No. of stand (see Fig. 1) & 3 & 3 & 3 & 6 & 5 & 5 & 1 & 5 & 5 & 5 & 1 & 4 & 4 & 1 & 3 & 3 & 3 & 3 & 5 & 5 & 5 & 6 & 6 & 6 & 6 & 2 & 6 & 8 & 7 & 7 & 7 & 7 \\
\hline \multirow{2}{*}{ No. of relevé/plot } & & & 1 & 2 & 1 & 1 & & 1 & 1 & 1 & & 1 & 1 & & 1 & & & & 1 & 2 & 2 & 2 & 2 & 2 & 2 & & 2 & 3 & 2 & 2 & 3 & 3 \\
\hline & 8 & 9 & 1 & 3 & 5 & 6 & 3 & 4 & 9 & 8 & 2 & 2 & 3 & 1 & 0 & 5 & 6 & 7 & 7 & 0 & 1 & 2 & 5 & 6 & 7 & 4 & 4 & 2 & 8 & 9 & 0 & 1 \\
\hline \multirow{2}{*}{ No. of clusters } & \multicolumn{18}{|c|}{$\mathrm{I}$} & \multicolumn{14}{|c|}{ II } \\
\hline & \multicolumn{10}{|c|}{ III } & \multicolumn{8}{|c|}{ IV } & & & & & Y & & & & & & & & II & \\
\hline Taraxacum balticum & - & - & - & - & - & - & - & - & - & - & 1 & - & - & 1 & 3 & 4 & 3 & 3 & 2 & - & 3 & - & - & - & 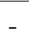 & - & - & - & - & - & - & - \\
\hline Taraxacum copidophyllum & - & - & - & - & - & - & - & - & - & - & - & 2 & - & - & - & - & - & - & - & - & - & - & - & - & - & - & - & - & - & - & - & - \\
\hline Taraxacum cordatum & - & - & - & - & - & - & - & - & - & - & - & - & - & - & - & - & - & - & - & - & - & - & - & - & - & - & - & 2 & - & - & - & - \\
\hline Taraxacum fagerstroemii & - & - & - & - & - & - & - & - & - & - & - & 1 & - & - & - & - & - & - & - & - & - & - & - & - & - & - & - & - & - & - & - & - \\
\hline Taraxacum fusciflorum & - & - & - & - & - & - & - & - & - & - & - & - & - & - & - & - & - & - & - & - & - & - & - & - & - & - & - & - & 3 & - & - & - \\
\hline Taraxacum gelertii & 3 & - & - & - & - & - & - & - & - & - & 2 & - & 3 & - & - & - & 1 & - & - & - & - & - & - & - & - & - & 3 & - & - & - & - & - \\
\hline Taraxcaum gentile & - & - & - & - & - & - & - & - & - & - & 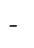 & - & - & - & - & - & - & - & - & - & - & - & - & - & - & - & - & - & - & 3 & - & - \\
\hline Taraxacum haematicum & - & - & - & - & - & - & 2 & 3 & 2 & 2 & 3 & - & 2 & - & - & - & - & - & - & - & - & - & 3 & - & 3 & 2 & - & - & - & - & - & 3 \\
\hline Taraxacum hemicyclum & - & - & - & - & - & - & - & - & - & - & - & - & 1 & - & - & - & - & - & - & - & - & - & - & - & - & - & - & - & - & - & - & - \\
\hline Taraxacum hamatiforme & 3 & - & 3 & - & 2 & 3 & - & - & 2 & 3 & 2 & - & - & - & - & - & - & - & - & - & - & - & - & - & - & - & - & - & - & - & - & - \\
\hline Taraxacum hamatum & 2 & - & - & - & - & - & - & - & - & - & 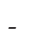 & - & - & - & - & - & - & - & - & - & - & - & - & - & - & - & - & - & - & - & - & - \\
\hline Taraxacum infestum & - & 2 & - & - & - & - & - & - & - & - & - & - & - & - & - & - & - & - & - & - & - & - & - & - & - & - & - & - & - & - & - & - \\
\hline Taraxacum kernianum & - & - & - & - & - & 1 & - & - & - & - & - & - & - & - & - & - & - & - & - & - & - & - & - & - & - & - & - & - & - & - & - & - \\
\hline Taraxacum lancidens & - & - & - & 2 & - & - & - & - & - & - & 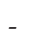 & - & - & - & - & - & - & - & - & - & - & - & - & - & - & - & 3 & - & - & - & - & - \\
\hline Taraxacum laticordatum & - & - & - & - & 1 & - & - & - & - & - & - & - & - & - & - & - & - & - & - & - & - & - & - & - & - & - & - & - & - & - & - & - \\
\hline Taraxacum leptodon & - & - & - & 3 & - & - & - & - & - & - & - & - & - & - & - & - & - & - & - & - & - & 3 & - & - & - & - & - & - & - & & - & - \\
\hline Taraxacum latissimum & - & - & - & - & - & - & - & - & - & - & - & - & - & - & - & - & - & - & - & - & - & 2 & - & - & - & - & - & - & - & - & - & - \\
\hline Taraxacum lucidum & - & - & - & - & - & - & - & - & - & - & - & - & - & - & - & - & - & - & - & - & - & - & - & - & - & 1 & - & - & - & - & - & - \\
\hline Taraxacum nordstedtii & 3 & 3 & 4 & - & - & - & - & - & 2 & 3 & - & 2 & 3 & 1 & 2 & 2 & 2 & - & - & 3 & - & - & - & - & - & - & - & - & - & & - & - \\
\hline Taraxacum ostenfeldii & - & - & - & - & 1 & - & - & - & - & - & - & - & - & - & - & - & - & - & - & - & - & - & - & - & - & - & - & - & - & - & - & - \\
\hline Taraxacum piceatum & - & - & - & - & 1 & - & - & - & - & - & - & - & - & - & - & - & - & - & - & - & - & - & - & - & - & - & - & - & - & - & - & - \\
\hline Taraxacum pulchrifolium & - & - & - & - & - & - & - & - & - & - & - & - & - & - & - & - & - & - & - & - & - & - & - & - & - & - & - & - & - & - & 3 & - \\
\hline Taraxacum sellandii & - & - & 2 & - & 2 & - & - & - & - & - & - & - & 2 & - & - & - & - & - & - & - & - & - & - & 4 & - & - & - & - & - & - & - & - \\
\hline Taraxacum sertatum & - & - & - & - & - & - & - & - & - & 1 & - & - & - & - & - & - & - & - & - & - & - & - & - & - & - & - & - & - & - & - & - & - \\
\hline Taraxacum sinuatum & - & - & - & - & - & - & - & - & - & - & - & 2 & - & - & - & - & - & - & - & - & - & - & - & - & - & - & - & - & - & - & - & - \\
\hline Taraxacum stenoglossum & - & - & - & - & - & - & - & - & - & - & - & - & - & - & - & - & - & - & - & - & - & - & - & 3 & - & - & - & - & - & - & - & - \\
\hline Taraxacum sublaeticolor & - & - & - & - & - & - & - & - & - & - & - & 1 & 1 & - & - & - & - & - & - & - & - & - & - & - & - & - & - & - & - & - & - & - \\
\hline Agrostis stolonifera & 4 & 4 & 5 & - & 5 & - & 5 & 6 & 6 & 6 & 4 & 3 & 6 & 6 & 6 & 6 & 6 & 7 & 6 & 7 & 7 & 4 & 5 & 6 & - & 7 & - & 7 & 6 & 7 & 6 & - \\
\hline Alopecurus geniculatus & - & - & - & - & - & - & - & - & - & - & - & - & - & - & - & - & - & - & - & - & - & - & - & - & - & 2 & - & - & - & - & - & 7 \\
\hline Alopecurus pratensis & - & - & - & 3 & 6 & - & - & 1 & - & 4 & 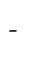 & - & - & - & - & - & - & - & - & - & - & - & - & 2 & - & - & - & - & 3 & - & - & - \\
\hline Anthoxanthum odoratum & 5 & 6 & - & - & - & - & - & - & - & 2 & 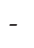 & - & - & - & - & - & 2 & - & - & - & 1 & - & - & - & - & - & - & 2 & - & - & - & - \\
\hline Aster tripolium & - & - & - & - & - & - & - & - & - & - & - & - & - & - & - & - & - & - & - & - & - & 2 & 3 & - & - & 2 & - & - & - & - & - & - \\
\hline Atriplex prostrata ssp. & - & - & - & - & - & - & - & - & - & - & - & - & - & - & - & - & - & - & - & - & - & 1 & - & - & - & 2 & - & - & - & - & - & - \\
\hline Berula erecta & - & - & - & - & - & - & - & - & - & - & 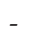 & - & - & - & - & - & 2 & - & - & - & - & - & - & - & - & - & - & - & - & - & - & - \\
\hline Blysmus compressus & - & - & - & - & - & - & - & 1 & 4 & - & - & - & - & - & - & 2 & 3 & 3 & 4 & 3 & 5 & - & - & - & - & - & - & - & - & - & - & - \\
\hline Brachythecium rutabulum & - & - & - & - & - & 3 & - & - & 3 & - & - & - & 3 & - & - & - & - & - & 5 & - & - & - & - & - & - & - & - & - & - & - & - & - \\
\hline Briza media & - & - & - & - & - & - & - & - & - & - & - & - & - & - & - & - & - & - & - & 2 & - & - & - & - & - & - & - & - & - & - & - & - \\
\hline Caliergonella cuspidata & - & - & - & - & - & 3 & - & - & - & - & - & 8 & 9 & - & 9 & 9 & 9 & 9 & - & - & - & - & - & - & - & - & - & - & - & - & - & - \\
\hline Caltha palustris & - & - & - & 3 & - & - & - & - & - & - & - & 2 & 2 & - & 2 & - & 2 & - & - & - & - & - & - & - & - & - & - & - & - & - & - & - \\
\hline Carex cuprina & - & - & - & - & - & - & - & - & - & - & 3 & - & - & - & - & - & - & - & 2 & 3 & - & - & - & - & - & - & - & - & - & - & 2 & - \\
\hline Carex disticha & - & - & - & 6 & - & - & - & - & 3 & - & - & 6 & 4 & - & 2 & - & 3 & 2 & - & - & - & - & - & - & - & - & - & - & 6 & - & - & 3 \\
\hline Carex distans & - & - & - & - & - & - & - & - & - & - & & - & - & - & - & - & - & - & 3 & - & 4 & - & - & - & - & - & - & - & - & - & - & - \\
\hline Carex hirta & - & - & - & - & 2 & - & - & - & - & - & - & - & - & - & - & - & - & - & - & 2 & - & - & - & - & - & - & - & - & - & - & - & - \\
\hline Carex nigra & - & 5 & 6 & 4 & 3 & 7 & 5 & 6 & 6 & 4 & 4 & 3 & 6 & 3 & 6 & 3 & 3 & 2 & 3 & 3 & 3 & - & - & - & - & - & - & - & - & & - & - \\
\hline Carex panicea & - & - & 3 & - & - & - & - & - & - & - & & - & 3 & - & - & 3 & 2 & 2 & - & 2 & 3 & - & - & - & - & - & 3 & 3 & - & - & - & - \\
\hline Cardamine pratensis & - & 3 & 2 & 2 & 3 & 3 & - & - & 2 & 3 & 2 & 2 & 2 & 2 & 3 & 3 & 2 & 2 & - & 2 & - & - & - & - & - & - & - & - & 2 & - & - & - \\
\hline Centaurea jacea & - & - & - & 3 & - & - & - & - & - & - & & - & - & - & 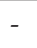 & 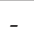 & - & - & - & - & - & - & - & 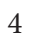 & - & - & 4 & - & - & - & - & - \\
\hline Cerastium holosteoides & - & - & - & - & - & - & 2 & 2 & - & 1 & . & - & - & 2 & - & - & - & - & 1 & - & - & - & - & - & 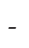 & - & - & - & - & & - & - \\
\hline
\end{tabular}


Tab. 3. Continued

\begin{tabular}{|c|c|c|c|c|c|c|c|c|c|c|c|c|c|c|c|c|c|c|c|c|c|c|c|c|c|c|c|c|c|c|c|c|}
\hline No. of stand (see Fig. 1) & 3 & 3 & 3 & 6 & 5 & 5 & 1 & 5 & 5 & 5 & 1 & 4 & 4 & 1 & 3 & 3 & 3 & 3 & & 5 & & 6 & 6 & 6 & 6 & & 6 & 8 & & 7 & & 7 \\
\hline \multirow{2}{*}{ No. of relevé/plot } & & & 1 & 2 & 1 & 1 & & 1 & 1 & 1 & & 1 & 1 & & 1 & & & & 1 & 2 & & 2 & 2 & 2 & 2 & & 2 & 3 & & 2 & 3 & 3 \\
\hline & 8 & 9 & 1 & 3 & 5 & 6 & 3 & 4 & 9 & 8 & 2 & 2 & 3 & 1 & 0 & 5 & 6 & 7 & 7 & 0 & 1 & 2 & 5 & 6 & 7 & 4 & 4 & 2 & 8 & 9 & 0 & 1 \\
\hline \multirow{2}{*}{ No. of clusters } & \multicolumn{18}{|c|}{$\mathrm{I}$} & \multicolumn{14}{|c|}{ II } \\
\hline & \multicolumn{10}{|c|}{ III } & \multicolumn{8}{|c|}{ IV } & & & & & V & & & & & & & $\mathrm{V}$ & & \\
\hline Chenopodium rubrum & - & - & - & - & - & - & - & - & - & - & & - & - & & - & - & - & - & & 2 & & - & - & - & - & & - & - & & - & - & - \\
\hline Cirsium arvense & - & - & - & - & 2 & 2 & - & 2 & - & 2 & & - & - & & - & - & - & - & - & - & - & 2 & - & - & - & - & - & - & & - & - & - \\
\hline Dactylorhiza incarnata & - & - & 2 & - & - & - & - & - & - & - & - & - & - & - & - & - & - & 1 & - & - & - & - & - & - & - & 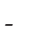 & - & - & & - & - & - \\
\hline Dactylorhiza majalis & - & - & 3 & - & - & - & - & - & 2 & - & - & - & - & - & - & - & - & - & 3 & 4 & - & 1 & - & - & - & & 2 & 1 & - & - & - & - \\
\hline Deschampsia caespitosa & - & 4 & - & - & - & - & - & - & - & 5 & 4 & 4 & - & - & - & - & - & - & - & - & - & - & - & - & - & - & 7 & 3 & - & - & - & - \\
\hline Eleocharis palustris & - & - & - & - & - & - & - & - & - & - & 4 & - & 3 & - & - & - & - & - & - & - & - & - & 3 & - & - & - & 3 & - & - & - & - & - \\
\hline Eleocharis uniglumis & - & - & - & - & - & - & - & - & - & - & - & - & - & 4 & - & 3 & - & 3 & 4 & 3 & 4 & 2 & - & 3 & 3 & - & - & 3 & 4 & 4 & 6 & 6 \\
\hline Elytrygia repens & 5 & 5 & 5 & - & - & 3 & - & 3 & - & - & 3 & 2 & 1 & & - & 3 & 3 & 2 & - & - & - & - & - & - & - & 3 & - & - & 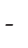 & - & - & - \\
\hline Eriophorum angustifolium & - & - & 2 & - & - & - & - & - & - & - & & - & - & - & - & 2 & 3 & 2 & - & - & - & - & - & - & - & - & - & - & - & - & - & - \\
\hline Festuca arundinacea & - & - & - & - & - & - & - & - & - & - & - & - & - & - & - & - & - & - & - & - & - & - & - & - & - & 2 & - & 3 & - & - & - & - \\
\hline Festuca rubra & 2 & 3 & 4 & 5 & - & - & - & - & - & - & 6 & - & 3 & - & 6 & 4 & 5 & - & 3 & - & 4 & 7 & 7 & 7 & 8 & 2 & 6 & 4 & - & - & 6 & - \\
\hline Galium palustre & - & - & - & - & 2 & 2 & - & - & - & - & - & - & - & - & - & 2 & - & - & 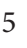 & - & - & - & - & - & - & - & - & - & - & - & - & - \\
\hline Glaux maritima & - & - & - & - & - & - & - & - & - & - & - & - & - & - & - & - & 2 & 3 & - & 4 & 3 & 4 & 4 & 3 & 4 & 2 & - & 3 & - & - & - & - \\
\hline Holcus lanatus & - & - & - & 3 & 4 & 4 & - & 4 & - & - & & - & - & - & - & - & - & - & 2 & - & - & - & - & - & - & & - & - & - & - & - & - \\
\hline Hydrocotyle vulgaris & - & - & - & - & - & - & - & - & - & - & - & - & - & - & 3 & - & - & 2 & - & - & - & - & - & - & - & - & 2 & - & 2 & - & - & - \\
\hline Juncus articulatus & - & - & - & - & - & - & - & - & - & - & - & - & - & - & - & 2 & - & 3 & - & - & - & - & - & - & - & - & - & - & - & - & - & - \\
\hline Juncus compressus & - & - & - & - & - & - & - & - & - & - & - & 3 & 3 & - & - & - & - & - & - & - & - & - & - & - & - & - & - & - & - & - & - & - \\
\hline Juncus effusus & 6 & - & 4 & 3 & 3 & 5 & 3 & 2 & 2 & - & 4 & 2 & - & 3 & - & - & - & - & - & - & - & - & - & - & - & - & - & - & - & - & - & 2 \\
\hline Juncus gerardi & - & - & - & - & - & - & 4 & 2 & - & - & 5 & - & - & 7 & - & 6 & 5 & 5 & 5 & - & 3 & 5 & 6 & 5 & - & 3 & - & - & - & - & - & - \\
\hline Kindbergia praelonga & - & - & - & - & - & - & - & - & - & - & - & - & - & - & - & - & - & - & - & - & - & - & 6 & - & - & - & - & - & - & - & - & - \\
\hline Leontodon autumnalis & - & - & - & - & 2 & 2 & 2 & 3 & - & - & 3 & - & - & 3 & - & 2 & 2 & 2 & 3 & - & 2 & - & 3 & - & 2 & 3 & - & - & - & - & - & - \\
\hline Leptodictyum riparium & - & - & - & - & - & - & - & - & - & - & - & - & - & - & - & - & - & - & 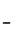 & - & - & - & - & - & - & - & - & - & 4 & - & - & - \\
\hline Lotus tenuis & - & - & - & - & - & - & - & - & - & - & - & - & - & - & - & - & - & - & - & - & - & - & - & - & - & 4 & - & - & - & - & - & - \\
\hline Lotus uliginosus & - & - & - & - & - & - & - & - & - & - & 2 & 2 & 2 & 2 & 2 & - & - & - & - & - & - & - & - & - & - & - & 2 & 3 & - & - & - & - \\
\hline Luzula multiflora & 3 & - & - & - & - & - & - & - & - & 2 & - & - & - & - & - & - & - & - & - & - & - & - & - & - & - & - & - & - & - & - & - & - \\
\hline Lychnis flos-cuculi & - & - & 2 & - & 3 & 2 & - & - & - & - & - & - & - & - & 2 & 2 & 2 & 2 & - & - & 1 & - & - & - & - & - & - & - & - & - & - & - \\
\hline Lysimachia nummularia & - & - & - & - & - & - & - & - & - & - & - & 3 & 3 & - & 2 & - & - & - & - & - & - & - & - & - & - & - & - & - & - & - & - & - \\
\hline Mentha aquatica & - & - & - & - & - & - & - & - & - & - & - & - & - & - & 2 & 2 & 2 & 2 & - & - & - & - & - & - & - & - & - & - & - & - & - & - \\
\hline Phragmites australis & - & - & - & - & - & - & - & - & - & - & - & - & - & - & - & - & - & - & - & 2 & - & 3 & 4 & - & 3 & 3 & - & 4 & 5 & 7 & 6 & 6 \\
\hline Plantago lanceolata & 3 & - & 4 & - & - & - & - & - & - & 3 & - & 3 & - & - & - & 2 & - & - & 1 & - & - & - & 2 & - & - & - & - & - & - & - & - & - \\
\hline Plantago maritima & - & - & - & - & - & - & - & - & - & - & - & - & - & - & - & - & - & 4 & 6 & 3 & - & 3 & 5 & 4 & 2 & 2 & 2 & 2 & - & - & - & - \\
\hline Plantago winteri & - & - & - & - & 2 & 2 & 2 & 3 & - & - & 2 & - & - & - & - & - & - & 2 & 3 & 3 & - & - & 2 & - & - & - & - & - & - & - & - & - \\
\hline Poa pratensis & - & - & - & - & - & - & - & - & - & - & - & 3 & - & - & - & - & - & - & - & 2 & - & - & - & - & - & - & - & - & - & - & - & - \\
\hline Potentilla anserina & 5 & - & - & 3 & 6 & 5 & 4 & 5 & 5 & 3 & 3 & 3 & - & 4 & 5 & 3 & 4 & 4 & 3 & 5 & - & 4 & 4 & 3 & 3 & 3 & 4 & 5 & 4 & 5 & 4 & 4 \\
\hline Ranunculus acer & - & 2 & - & 2 & 2 & 3 & 1 & - & 2 & 2 & 2 & 2 & 2 & 2 & - & 2 & 3 & - & - & 2 & 2 & - & - & 2 & - & - & 2 & 2 & - & - & - & - \\
\hline Ranunculus flammula & - & - & - & - & 2 & 1 & - & - & - & - & - & - & - & - & 2 & 2 & 2 & 2 & - & - & - & - & - & - & - & - & - & - & - & - & - & - \\
\hline Ranunculus repens & - & 3 & - & - & 6 & 2 & - & 3 & - & 4 & 3 & - & 3 & - & - & 3 & 3 & 3 & - & - & - & - & - & - & - & - & - & 2 & - & - & - & - \\
\hline Rhitidiadelphus squarrosus & 3 & 6 & 9 & - & - & - & - & - & - & - & - & - & - & - & - & - & - & - & - & - & - & - & - & - & - & - & - & - & - & - & - & - \\
\hline Rumex acetosa & 2 & 3 & - & 2 & 2 & - & - & 2 & - & - & - & 2 & - & 2 & 2 & - & - & - & - & - & - & - & - & - & - & - & - & - & - & - & - & - \\
\hline Rumex crispus & - & 2 & - & - & - & - & - & 1 & - & - & - & - & 2 & 2 & 2 & - & - & - & - & - & - & - & - & - & - & - & - & - & 2 & 2 & 1 & 2 \\
\hline Schoenoplectus tabernaemonatni & - & - & - & - & - & - & - & - & - & - & - & - & - & - & - & - & - & - & 3 & - & - & - & 2 & - & - & - & - & - & - & - & 3 & - \\
\hline Sonchus arvensis & - & - & - & - & - & - & - & - & - & - & - & - & - & - & - & - & - & - & - & - & - & 3 & - & 2 & 2 & - & - & - & - & - & - & - \\
\hline Tortula truncata & - & - & - & - & - & - & - & - & - & - & - & - & - & - & - & - & - & - & 3 & - & - & - & - & - & - & - & - & - & - & - & - & - \\
\hline Trifolium fragiferum & - & - & - & - & 4 & - & 5 & 3 & 3 & - & - & 3 & 4 & 3 & - & 3 & 2 & 4 & 3 & 3 & 3 & 2 & - & 3 & 3 & 6 & - & 2 & - & - & - & - \\
\hline Trifolium repens & 4 & - & 5 & - & 4 & 3 & 4 & 4 & 4 & 4 & 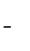 & - & - & 5 & 4 & 4 & 3 & - & 4 & 4 & 5 & 3 & - & - & - & - & - & - & - & - & - & - \\
\hline Triglochin maritimum & - & - & 2 & 4 & - & - & 3 & 3 & - & 2 & 5 & 3 & 3 & 3 & 3 & 5 & 6 & 7 & 5 & 5 & & - & 4 & - & 5 & 6 & 3 & - & 4 & 3 & - & 1 \\
\hline Triglochin palustre & - & - & - & - & - & - & - & - & - & - & & - & 2 & - & - & - & - & 2 & - & - & - & - & - & - & - & 2 & 4 & - & - & - & - & - \\
\hline Valeriana dioica & - & - & - & - & - & - & - & - & - & - & - & - & 2 & & - & 3 & 3 & 2 & - & - & - & - & - & - & - & - & - & - & - & - & - & - \\
\hline
\end{tabular}


only in single plots. Phytocoenoses from cluster VI showed the highest contribution of Phragmites australis (albeit of reduced vitality) and the lowest number of species, including T. fusciflorum, T. gentile and T. pulchrifolium occurring only in this group.

\section{Discussion}

Dandelion microspecies frequently occur sympatrically, which is probably the rule in the whole area supporting agamospermous forms. Due to their reproductive isolation, obligately agamospermous microspecies can be constant coexisting taxa (Uhlemann 2001). A possible underlying cause of the coexistence may be a small-scale environmental heterogeneity. Unfortunately, details of dandelion microspecies' habitat requirements are still scarce and are mainly of a phytosociological nature or represent Ellenberg's intermediate indication values (e.g. Sterk et al. 1983, Schmid 2002). Moreover, as suggested by comparative studies on the seed germination ecology of some Taraxacum microspecies, ecological differentiation is commonly among the microspecies and plays an important role in the maintenance of the taxonomic diversity within the genus (van Loenhoud and Duyts 1981). The genotype-environment interactions in apomictic dandelion populations have been studied (without microspecies identification) in recent years, some of the studies showing very small-scale local ecological adaptations (Vellend et al. 2009, Drumond et al. 2012, McLeod et al. 2012). In Poland, the genus Taraxacum is represented by three very rare sexual diploids and by about 400 apomictic species from 12 sections (Mirek et al. 2002). We recorded a relatively high dandelion flora diversity (27 microspecies) in the coastal salt and brackish meadows visited. The typical low-sward phytocoenoses representative of the habitat currently occupy a small (less than 400 hectares) area along the Polish Baltic coast (Bosiacka 2012). The salt grasslands were reduced in size mainly due to cessation of grazing and mowing. Research on the dandelion flora conducted in the Netherlands demonstrated that the number of microspecies depends on the intensity of grassland management: the highest densities of dandelion taxa (up to 19 microspecies per $125 \mathrm{~m}^{2}$ ) were typical of the most intensively fertilized and grazed pastures, while extensively managed, ungrazed and unfertilized grasslands support much lower numbers of Taraxacum microspecies. This effect concerns mainly the section Taraxacum (Ruderal$i a$ ), dandelions in which the number of specimens as well as the number of microspecies increase when more intensive farming is practiced; however, the total number of dandelions (microspecies and individuals) decreases rapidly under constant management (Oosterveld 1983, Sterk et al. 1983). Our results correspond with the positive effect of soil fertility on the number of dandelion microspecies, observed in the studies referred to above.

Dandelions of each section are found under a specific set of environmental conditions; for example, microspecies from the section Palustria are almost exclusively confined to natural and semi-natural habitats and are usually found in periodically flooded sites, with an accompanying effect of new minerals available from the sediments (Kirschner and Štěpanek 1998, Schmid 2002, Marciniuk 2012); microspecies from the section Celtica prefer plots under relatively low organic manuring and are found in meadows, pastures, as well as along roads in urban areas (Horn et al. 1996, Trávníček et al. 2010); microspecies from the section Taraxacum (Ruderalia) prefer regularly fertilized grasslands and various anthropogenic habitats; as the summer habitat dry-out is probably the main factor limiting their occurrence, they are often found in areas affected by the maritime climate (Sterk et al. 1983, Trávníček et al. 2010); microspecies from the section Hamata are usually found in moist meadows, preferably with lower $\mathrm{pH}$, an intermediate mineral content and a partly disturbed vegetation, as well as in shaded places in urban areas (Øllgaard 1983, Trávníček and Vašut 2011). Oosterveld (1983) conducted one of the few direct studies on the ecological preferences (involving soil properties) of individual dandelion microspecies. He examined soil phosphate concentrations in the immediate vicinity of the root system of the microspecies co-occurring in a pasture. His results allowed the presumption that the high variability within Taraxacum may be associated with increasing rate of phosphate availability. He also classified the dandelion microspecies in relation to management invariability (Oosterveld 1978). In another detailed study, Bosiacka et al. (2016) determined soil properties and identified plant communities associated with marsh dandelions in Polish and Estonian coastal grasslands. Soil salinity was found to correlate moderately strongly albeit significantly with all the three marsh dandelion microspecies found (positive correlation for Taraxacum balticum and negative correlation for T. suecicum and T. decolorans). In addition, T. suecicum was inversely correlated with the organic matter content and was positively correlated with soil $\mathrm{pH}$. A much higher number of T. balticum stands (22 stands, 36 samples) was found on the Estonian coast than in the Polish coastal grasslands. The taxon occurred there in the widest ranges of all soil properties considered and in all types of phytocoenoses studied: in salt and brackish meadows, in coastal alvar grasslands and in transitional areas.

All the dandelion-supporting meadows visited along the Polish Baltic coast are currently, or had been until recently (in the previous decade), extensively used. Usually, the meadows showed a mosaic of wet halophytic and glycophytic vegetation patches on a peat substrate. At some sites, small areas of mineral inclusions were scattered among peat deposits. In addition, many sites showed evidence of wild boar rooting. Therefore, the spatial and taxonomic structure of the vegetation was locally very heterogeneous. The overall contribution of dandelions to coastal meadow phytocoenoses was low. Analysis of relationships between the species composition of the meadows studied and the soil properties revealed a few statistically significant variables, including soil fertility as the most important one, followed by the organic matter content, $\mathrm{pH}$, available magnesium content, and salinity. The available phosphorus content proved non-significant, as opposed to the study of Oosterveld (1983). Most of the dandelion microspecies we found were associated with relatively fertile and lowest-salinity soils. Only four microspe- 
cies of the section Taraxacum (Ruderalia): T. latissimum, $T$. stenoglossum, T. pulchrifolium and T. lucidum were found in single patches with the lowest fertility and the highest salinity. The ecological spectrum of those species is very wide; they occur in wet meadows and in miscellaneous anthropogenic grassy habitats, including roadsides and highly salted urban lawns (Trávníček et al. 2010). A few microspecies (T. infestum, T. cordatum, T. hamatum, T. sertatum) occurred on soils with the lowest organic matter content and the lowest $\mathrm{pH}$. Among them, T. cordatum is known to prefer sandy soil, and can penetrate even a very dry dune environment which is the domain of the section Erythrosperma (Sterk et al. 1983). Our specimens, often buried in sand, were found in a brackish meadow adjacent to coastal dunes, the only site of this type among the ones we surveyed. Taraxacum balticum was found during our fieldwork in phytocoenoses with a high contribution of halophytes. Kirschner and Štěpanek (1998) define the microspecies as one of the most halophilous dandelions, its distribution range being closely connected with the Baltic coast. Like other taxa of the section Palustria, it is becoming less and less common. None of our sites supporting the microspecies has been previously reported in the literature. Apart from the coast, T. balticum has been reported from only one inland salt grassland and one chalk meadow in central Poland (Marciniuk 2012). Taraxacum nordstedtii was the most common microspecies in our study in the western part of the coast, and occurred both in typically halophytic phytocoenoses and along their edges,

\section{References}

Bakker, J. P., 2012: Restoration of salt marshes. In: van Andel, J., Aronson, J. (eds.), Restoration ecology, 248-262. The New Frontier, Blackwell Publishing.

Bosiacka, B., 2012: 1330 Coastal salt marshes (Glauco-Puccinellietalia part - coastal communities). In: Mróz, W. (ed.), Monitoring of habitats. Methodological guide. Part II, 72-84. Biblioteka Monitoringu Środowiska, Warszawa (in Polish).

Bosiacka, B., Podlasiński, M., Pieńkowski, P., 2011: Salt marshes conditioned by ascending brine in Northern Poland: land-use changes and vegetation-environment relations. Phytocoenologia 41, 201-213.

Bosiacka, B., Kull, T., Więcław, H., Marciniuk, P., Podlasiński, M., 2016: Habitat requirements of marsh dandelions (Taraxacum sect. Palustria) in Polish and Estonian coastal grasslands. Polish Journal of Ecology 64, 213-230.

Dijkema, K. S., 1990: Salt and brackish marshes around the Baltic sea and adjacent parts of the North Sea: their vegetation and management. Biological Conservation 51, 191-209.

Drummond, E. B. M., Vellend, M., 2012: Genotypic diversity effects on the performance of Taraxacum officinale populations increase with time and environmental favorability. PloS One 7, e30314.

Dudman, A. A., Richards, A. J., 1997: Dandelions of Great Britain and Ireland. Botanical Society of the British Isles, London.

Emeis, K. C., Struck, U., Blanz, T., Kohly, A., Voß, M., 2003: Salinity changes in the central Baltic Sea (NW Europe) over the last 10000 years. The Holocene 13: 411-421.

Głowacki, Z., Øllgaard, H., Krechowski, J., 2004: Genus Taraxacum in the herbarium of University of Silesia. Badania Fizjograficzne nad Polską Zachodnią 53, 107-112. among glycophytes. The microspecies has the widest ecological spectrum of all the species of the section Celtica (Sterk et al. 1983, Kirschner and Štěpanek 1984, Horn et al. 1996). Based on qualitative inventories of grasslands under different management conditions in the Netherlands, and according to the classification of dandelion microspecies associated with low to highly dynamic habitats, T. nordstedtii is a low-dynamic species and is the last to disappear under stable mowing conditions (Oosterveld 1978, 1983). In Poland, it is a rare microspecies, occurring at the eastern limit of its range; it has been previously known from only two stands: the Chrząszczewo Island (Øllgaard et al. 2000) and Tułowice in Upper Silesia (Głowacki et al. 2004).

Our results have a limited generalization potential, as the number of sites with identified microspecies was low. Nevertheless, the information obtained increases the still insufficient body of knowledge on ecological spectra of individual dandelion microspecies, hence their potential indicator properties. The dominance of microspecies associated with the most fertile patches of coastal meadows may mean that a steady supply of available new nutrients is a common feature of dandelion growth. The highest number of dandelion microspecies recorded in meadows with the most heterogeneous spatial structure, produced by, e.g. commonly observed wild boar rooting, seems to be consistent with the accepted assumption that dandelions exhibit many characteristics of colonizers and prefer open or sparsely covered spots in a stand for their settlement.
Herbich, J., 2004: 1330 Coastal salt marshes (Glauco-Puccinellietalia part - coastal communities). In: Herbich, J. (ed.), Marine and coastal habitats, coastal and inland salt marshes and sand dunes. Guide to the protection of Natura 2000 habitats and species, 86-93. Ministerstwo Środowiska, Warszawa (in Polish).

Hill, M. M., Šmilauer, P., 2005: TWINSPAN for Windows version 2.3. Huntington and Ceske Budejovice: Center for Ecology and Hydrology and University of South Bohemia.

Horn, K., Elsner, O., Meierott, L., Schmid, M., Wurzel, W., 1996: Verbreitung, Vergesellschaftung, Ökologie und Gefährdung von Taraxacum nordstedtii Dahlst. in Bayern. Berichte der Bayerischen Botanischen Gesellschaft 66/67, 269-288.

Hulisz, P., Piernik, A., Mantilla-Contreras, J., Elvisto, T., 2016: Main driving factors for seacoast vegetation in the Southern and Eastern Baltic. Wetlands 36, 909-919.

Interpretation Manual of European Union Habitats, Eur 25., 2003: European Commission, DG Environmental Nature and Biodiversity.

Isselstein, J., Jeangros, B., Pavlu, V., 2005: Agronomic aspects of biodiversity targeted management of temperate grasslands in Europe - a review. Agronomy Research 3, 139-151.

Kaczor, D., 2006: The salinity of groundwater in Mesozoic and Cenozoic aquifers of NW Poland - origin and evolution. Studia Geologica Polonica 126, 5-76.

Kirschner, J., Štěpanek, J., 1984: Taraxacum (Spectabilia) nordstedtii DAHLST. in Central Europe (Studies in Taraxacum L.). Folia Geobotanica 19, 287-297.

Kirschner, J., Štěpánek, J., 1996. Modes of speciation and evolution of the sections in Taraxacum. Folia Geobotanica 31, 415-426. 
Kirschner, J., Štěpanek, J., 1998: A monograph of Taraxacum sect. Palustria. Institute of Botany, Academy of Sciences of the Czech Republic, Pruhonice.

Kirschner, J., Drábkowá, L. Z., Štěpánek, J., Uhlemann, I., 2015: Towards a better understanding of the Taraxacum evolution (Compositae-Cichorieae) on the basis of nrDNA of sexually reproducing species. Plant Systematics and Evolution 301, 1135-1156.

Krzywiec, P., 2009: Geometry and evolution of selected salt structures in the Polish Lowlands in the light of seismic data. Przegląd Geologiczny 57, 812-818.

Lundevall, C. F., Øllgaard, H., 2006: Seven new Taraxacum species (Asteraceae, Cichorieae) from Norden. Willdenowia 36, 671-688.

Marciniuk, J., 2012: Taraxacum sect. Palustria in Poland. Rozprawa Naukowa 14. Wydawnictwo Uniwersytetu PrzyrodniczoHumanistycznego, Siedlce (in Polish).

Marciniuk, P., Musiał, K., Joachimiak, A., Marciniuk, J., Oklejewicz, K., Wolanin, M., 2012: Taraxacum zajacii (Asteraceae), a new species from Poland. Annales Botanici Fennici 49, 387-390.

Mc Leod, K. A., Scascitelli, M., Vellend, M., 2012: Detecting smallscale genotype-environment interactions in apomictic dandelion (Taraxacum officinale) populations. Journal of Evolutionary Biology 25, 1667-1675.

Mirek, Z., Piękoś-Mirkowa, H., Zając, A., Zając, M., 2002: Flowering plants and pteridiophytes of Poland - a checklist. W. Szafer Institute of Botany, Polish Academy of Sciences, Kraków.

Muller, S., 2002: Appropriate agricultural management practices required to ensure conservation and biodiversity of environmentally sensitive grassland sites designated under Natura 2000. Agriculture, Ecosystems and Environment 89, 261-266.

Ochyra, R., Żarnowiec, J., Bednarek-Ochyra, H., 2003: Cenzus catalogue of Polish mosses. W. Szafer Institute of Botany, Polish Academy of Sciences, Kraków.

Øllgaard, H., 1983: Hamata, a new section of Taraxacum (Asteraceae). Plant Systematics and Evolution 141, 199-217.

Øllgaard, H., Głowacki, Z., Krechowski, J., 2000: Species of the genus Taraxacum (Asteraceae) in Poland. Part 1. Pomorze, Mazowsze i Podlasie. Fragmenta Floristica et Geobotanica 7, 5-62 (in Polish).

Oosterveld, P., 1978: The indicative significance of the genus Taraxacum for the management of grasslands. Gorteria 9, 188-193.

Oosterveld, P., 1983: Taraxacum species as environmental indicators for grassland management. Environmental Monitoring and Assessment 3, 381-389.
Richards, L. A., 1954: Diagnosis and improvement of saline and alkali soils. USDA. Agriculture Handbook 60, Washington D. C.

Schmid, M., 2002: Morphologie, Vergesellschaftung, Ökologie, Verbreitung und Gefährdung der Sumpf-Lowenzahne ( $\mathrm{Ta}$ raxacum sect. Palustria Dahlst., Asteraceae) Suddeutschlands. Bibliotheca Botanica 155, 1-194.

Statsoft Inc. 2011: Statistica (data analysis software system), v. 10.0. www. statsoft.com.

Sterk, A. A., Groenhart, M. C., Mooren, J. F. A., 1983: Aspects of the ecology of some microspecies of Taraxacum in the Netherlands. Acta Botanica Neerlandica 32, 385-415.

ter Braak, C. J. F., Šmilauer, P., 2002: CANOCO Reference Manual and User's Guide to Canoco for Windows: Software for Canonical Community Ordinantion (version 4.5). Microcomputer Power. Ithaca, NY, USA.

Trávníček, B., Kirschner, J., Štěpánek, J., 2008: Five new species of Taraxacum sect. Ruderalia from central Europe and Denmark. Preslia 80, 27-59.

Trávníček, B., Kirschner, J., Štepánek, J., Vašut, R. J., 2010: Taraxacum Wiggers. - dandelion. In: Štepánková, J. (ed.), Květena Českĕ Republiky 8, 23-269. Academia, Praha (in Polish).

Trávníček, B., Vašut, R. J., 2011: Notes of the genus Taraxacum in Slovakia. I. Taraxacum sect. Hamata: a new group of dandelion in Slovakia. Biologia 66, 595-603.

Uhlemann, I., 2001: Distribution of reproductive systems and taxonomical concepts in the genus Taraxacum F.H. Wigg. (Asteraceae, Lactuceae) in Germany. Feddes Repertorium 112, $15-35$.

Uhlemann, I., Kirschner, J., Øllgaard, H., Štěpánek, J., 2007: Four new species of Taraxacum sect. Ruderalia (AsteraceaeCichorieae) from Central Europe and Scandinavia. Phyton 47, 103-121.

van Dijk, P. J., 2003: Ecological and evolutionary opportunities of apomixis: insights from Taraxacum and Chondrilla. Philosophical transactions of the Royal Society of London B 358, 1113-1121.

van Loenhoud, P. J., Duyts, H., 1981: A comparative study of the germination ecology of some microspecies of Taraxacum Wigg. Acta Botanica Neerlandica 30, 161-182.

Vellend, M., Drummond, E. B. M., Muir, J. L., 2009: Ecological differentiation among genotypes of dandelions (Taraxacum officinale). Weed Science 57, 410-416.

Wanner, A. 2009: Management, biodiversity and restoration potential of salt grassland vegetation of the Baltic Sea: analyses along a complex ecological gradient. - PhD Thesis, University of Hamburg, Hamburg. 